\title{
Role of Helicobacter pylori Eradication in Chronic Spontaneous Urticaria: A Propensity Score Matching Analysis
}

This article was published in the following Dove Press journal: Clinical, Cosmetic and Investigational Dermatology

\section{Yan Guo \\ Hua-Ming Li \\ Wei-Qin Zhu \\ Zhen Li}

Department of Gastroenterology, Hangzhou Third People's Hospital, Hangzhou, 310009, People's Republic of China
Correspondence: Yan Guo

Department of Gastroenterology

Hangzhou Third People's Hospital, No. 38

West Lake Road, Shangcheng District,

Hangzhou, 310009, People's Republic of

China

Tel $+8657|87823| 58$

Fax +865718781448 I

Email yanguodrl@I63.com
Objective: To investigate the role of Helicobacter pylori (HP) eradication in chronic spontaneous urticaria (CSU) treatment.

Methods: Retrospective analysis was performed on the clinical data of 522 patients with CSU who underwent a HP breath test in Hangzhou Third People's Hospital between January 2018 and December 2019. The CSU-HP(+) group consisted of patients with CSU and HP infection, who were treated with antihistamines combined with HP eradication therapy. The CSU-HP(-) group consisted of patients with CSU alone, who were treated with antihistamines. Propensity score matching (PSM) analysis, using the nearest neighbor matching method on a 1:1 basis, was performed to ensure the characteristics of the CSU-HP(+) and CSU-HP(-) groups were similar. Factors, including age, gender, white blood cells, red blood cells, platelets, alanine transaminase, creatinine, immunoglobulin E, and pre-treatment urticaria activity score (UAS), were matched to obtain a balanced cohort of patients in each group. Therapeutic effects were compared after matching. $t$-tests, $X^{2}$ test, and McNemar's test were used for comparison between the two groups before and after matching.

Results: Patients in the $\mathrm{CSU}-\mathrm{HP}(+)$ group reported significantly more gastrointestinal symptoms than those in the CSU-HP(-) group. UAS scores in the second week of treatment were significantly different between the two groups. After 3 months, the recurrence rate in the CSU-HP(+) group was lower than in the CSU-HP(-) group.

Conclusion: Eradication of HP infection in patients with CSU helps relieve gastrointestinal symptoms, improves the therapeutic effect of CSU within 2 weeks, and reduces the recurrence rate 3 months after treatment.

Keywords: chronic urticaria, chronic spontaneous urticaria, Helicobacter pylori, eradication therapy

\section{Introduction}

Chronic urticaria (CU) is a common dermatological allergy, which occurs at an incidence of $0.1 \%-3 \%$ in the population. ${ }^{1,2}$ In 2013, the European Academy of Allergy and Clinical Immunology (EAACI) reclassified CU into chronic spontaneous urticaria (CSU) and induced urticaria. ${ }^{3}$ Of these, CSU is more common, accounting for almost $90 \%$ of cases. CSU presents as the spontaneous presence of wheals, angioedema, or both, which last for 6 weeks or more. Around 50\% of cases resolve spontaneously, especially when the disease duration is short. However, the condition can last for decades, and the cause can be hard to pinpoint. This can impact greatly on patients' treatment and quality of life. 
Helicobacter pylori (HP) is a gram-negative microaerobic bacteria, which mainly resides in gastric mucosal epithelial cells. It causes inflammation of the gastric mucosa and specific humoral and cellular immunity in the body. ${ }^{4} \mathrm{HP}$ infection is closely related to gastrointestinal diseases, such as peptic ulcer, MALT lymphoma, and gastric cancer. ${ }^{5}$ In recent years, the relationship between $\mathrm{HP}$ and $\mathrm{CU}$ has been increasingly studied, but remains controversial. Some studies confirm that HP infection leads to the occurrence of $\mathrm{CU}$ and that eradication of HP alleviates its symptoms. ${ }^{6-9}$ Others report no significant correlation between HP infection and $\mathrm{CU} \cdot{ }^{10-15}$ In a recent study in Japanese university students, allergic diseases were negatively associated with HP infection, especially in men. ${ }^{16}$ Furthermore, eradication of HP in healthy people can lead to urticaria. ${ }^{17}$ Shortcomings of existing studies include small sample size, single-center location and lack of blinding.

This study investigates the effect of HP eradication on patients with CSU combined with HP infection, compared to patients with CSU alone.

\section{Patients and Methods}

\section{Patients}

Data were collected from the information center of Hangzhou Third People's Hospital. The study included all patients diagnosed with CSU and treated in the dermatology department of our hospital, along with CSU patients treated for HP infection in the gastroenterology department, between January 2018 and December 2019. Results of HP breath tests conducted in the endoscopy center during the same period were also included. All patients aged 18-80 years who met CSU diagnostic criteria ${ }^{18}$ were included in this study. The exclusion criteria were: (1) treatment with antibiotics or hormones in the previous month; (2) untreated heart, liver, or kidney disease, tumors, or mental illness; (3) other skin, atopic or autoimmune diseases such as asthma, allergic rhinitis, systemic lupus erythematosus, or rheumatoid arthritis; (4) previous HP treatment; (5) interruption in HP treatment; (6) urticaria related to environmental changes, such as mood and temperature; (7) pregnant or lactating women; and (8) patients with incomplete clinical or interview data. A total of 522 patients with CSU were included in this study. Of these, 173 patients had a HP infection, and 349 patients did not. All patients gave informed consent. This study was approved by the Medical Ethics Committee of
Hangzhou Third People's Hospital. This study was conducted in accordance with the declaration of Helsinki. Written informed consent was obtained from all participants.

\section{Therapeutic Drugs}

Both groups received an antihistamine (cetirizine hydrochloride $10 \mathrm{mg}$ ), which was taken daily for 2 weeks. In addition, the CSU-HP $(+)$ group received HP eradication therapy, which consisted of one proton pump inhibitor and two antibiotics administered for 2 weeks.

\section{Outcome}

Data were collected on general indicators, including gender, age, routine blood tests, liver and kidney function, and serum IgE.

A ${ }^{14} \mathrm{C}$-UBT was performed using a HUBT-01P tester and a $\quad 0.75 \mathrm{U}{ }^{14} \mathrm{C}-\mathrm{UBT}$ cartridge (Sinocore Haidway Biotechnology Co, Ltd.). The procedure was carried out according to the kit instructions. The patients were tested on an empty stomach or two hours after a meal. Patients swallowed a capsule containing ${ }^{14} \mathrm{C}$-Urea $(0.75 \mathrm{uCi}, \mathrm{Ci}=$ $37 \mathrm{GBq}$ ) with $20 \mathrm{~mL}$ water. After resting for 25 minutes, each patient blew into a $\mathrm{CO}_{2}$ collector bottle through a catheter. Patients stopped blowing when the $\mathrm{CO}_{2}$ absorber changed from red to colorless. After gas collection, $4.5 \mathrm{~mL}$ scintillation liquid was added to the blown pipe, which was rinsed with methanol and sealed. The level of ${ }^{14} \mathrm{C}$ radioactivity was tested for 2 minutes with a YH0114C-liquid scintillation counter. A positive result was indicated by ${ }^{14} \mathrm{C}$ UBT $>100 \mathrm{DMP} / \mathrm{mmol} \mathrm{CO}_{2}$, while a negative result was indicated by ${ }^{14} \mathrm{C}-\mathrm{UBT}<100 \mathrm{DMP} / \mathrm{mmol} \mathrm{CO}_{2}$.

Severity scores in all CSU patients were observed before and after treatment. Scores were based on the urticaria activity score (UAS) developed by the EAACI/ GA2LEN/EDF/WAO in Europe and ranged from 0-6, depending on the degree of itching and the number of wound clusters.

Pruritus severity was rated on a scale of 0 to 3 , as follows: $0=$ none (no pruritus), $1=$ mild (pruritus not affecting daily life), 2 = moderate (pruritus affecting daily life), 3 = intense (pruritus modifying daily life and activities). The number of wheals was also graded from 0 to 3 : $0=$ none, $1=$ mild $(<20$ wheals $/ 24 \mathrm{~h}), 2=$ moderate (20-50 wheals/24 h), $3=$ intense $(50$ wheals/24h or large confluent areas of wheals). The UAS of each patient was calculated from the sum of the pruritus and wheal scores (Table 1). 
Table I Chronic Urticaria Activity Score

\begin{tabular}{|l|l|l|}
\hline Score & Number of Wheals & Pruritus \\
\hline 0 & None & None \\
\hline 1 & $\begin{array}{l}\text { Mild } \\
(<20 \text { wheals/24 hours) }\end{array}$ & $\begin{array}{l}\text { Mild } \\
\text { (not affect daily life) }\end{array}$ \\
\hline 2 & $\begin{array}{l}\text { Moderate } \\
(21-50 \text { wheals/24 hours) }\end{array}$ & $\begin{array}{l}\text { Moderate } \\
\text { (affect daily life) }\end{array}$ \\
\hline 3 & $\begin{array}{l}\text { Intense } \\
(>50 \text { wheals/24 hours or } \\
\text { large } \\
\text { Confluent areas of } \\
\text { wheals) }\end{array}$ & $\begin{array}{l}\text { Intense } \\
\text { (modify daily life and daily } \\
\text { activities) }\end{array}$ \\
\hline
\end{tabular}

\section{Statistical Methods}

Data were analyzed using SPSS26.0 statistical software. Propensity score matching (PSM) was used to match subjects on a 1:1 basis according to the nearest neighbor matching method, and the caliper value was 0.001 . Standardized differences were used to test the balance of the matched variables, and a difference $<10 \%$ indicated satisfactory balance. The data were assessed for normal distribution before statistical comparisons. Continuous data were expressed as mean \pm standard deviation. The $t$-test was used for between-group comparisons, and postPSM data were compared by paired sample $t$-test. Categorical data were compared by $X^{2}$ test, and postPSM data were compared by McNemar's test. A p value $<0.05$ was considered to be statistically significant.

\section{Results}

\section{Results Before PSM}

A total of 522 patients were enrolled in this study, including 173 in the CSU-HP(+) group and 349 in the CSU-HP (-) group (Figure 1). Before PSM, age, gender, and pretreatment UAS were significantly different between the two groups. There was no difference in WBC, RBC, PLT, ALT, and Cr (Table 2). After PSM, matched patients were included in each group (Table 3).

\section{Results After PSM}

After matching, there was no difference in age, gender, and pre-treatment UAS between the two groups $(\mathrm{p}>0.05)$. However, the number of patients with gastrointestinal symptoms in the CSU-HP(+) group was significantly higher than in the CSU-HP(-) group $(\mathrm{p}<0.05)$. After 2 weeks of treatment, the UAS scores in the two groups were significantly different $(\mathrm{p}<0.05)$. The treatment regimen followed by the CSU-HP(+) group was more effective than that of the CSU-HP (-) group, shown by a significantly lower recurrence rate at 3 months in the former group $(\mathrm{p}<0.05)$.

\section{Discussion}

$\mathrm{CU}$ is one of the commonest allergic diseases treated by dermatologists. It produces an edema reaction, which typically manifests as temporary wound clusters and itching, due to an increased permeability of small blood vessels in the skin and mucosa. ${ }^{19,20} \mathrm{CU}$ is caused by a variety of allergens ${ }^{21}$ and has a complex etiology, which includes immune and non-immune factors. Currently, it is believed that $\mathrm{CU}$ is caused by excessive levels of IgE antibodies. These mediate mast cells, activate basophil degranulation, release histamine and other active substances, increase the permeability of small blood vessels in the skin and mucosa, and dilate capillaries, causing a series of skin allergy symptoms.

Recent studies have shown that there is a correlation between CU and HP infection, which suggests that HP infection may be involved in the pathogenesis of CU. Several studies report that urticaria significantly improves in CU patients after eradication of HP, and HP infection may be an important reason for delay in the progression of the disease. ${ }^{4,6,8,22,23}$ Patients with $\mathrm{CU}$ and both positive or negative autologous serum tests show an equally significant reduction in UAS after eradication of HP infection by triple therapy. ${ }^{9}$ Furthermore, many patients with $\mathrm{CU}$ have associated gastrointestinal symptoms, which may be related to HP infection. ${ }^{24}$ In our study, gastrointestinal symptoms reported in the $\mathrm{CSU}-\mathrm{HP}(+)$ group included acid regurgitation, belching, heartburn, upper abdominal distension, and stomach ache or discomfort.

The EAACI's guidelines explicitly discuss the importance of HP infection monitoring in CU. ${ }^{3}$ In 2003, The American Academy of Dermatology also noted that when HP infection was successfully eradicated with antibiotics, urticaria was more likely to be resolved. Therefore, clinicians should: (1) conduct HP tests after considering other causes of urticaria, (2) use appropriate antibiotics if HP is present, and (3) confirm successful eradication of infection. ${ }^{25}$ However, the British Society for Allergy and Clinical Immunology guidelines do not recommend routine screening for HP due to limited evidence that eradication of HP will result in an improvement in $\mathrm{CU}{ }^{26}$ 


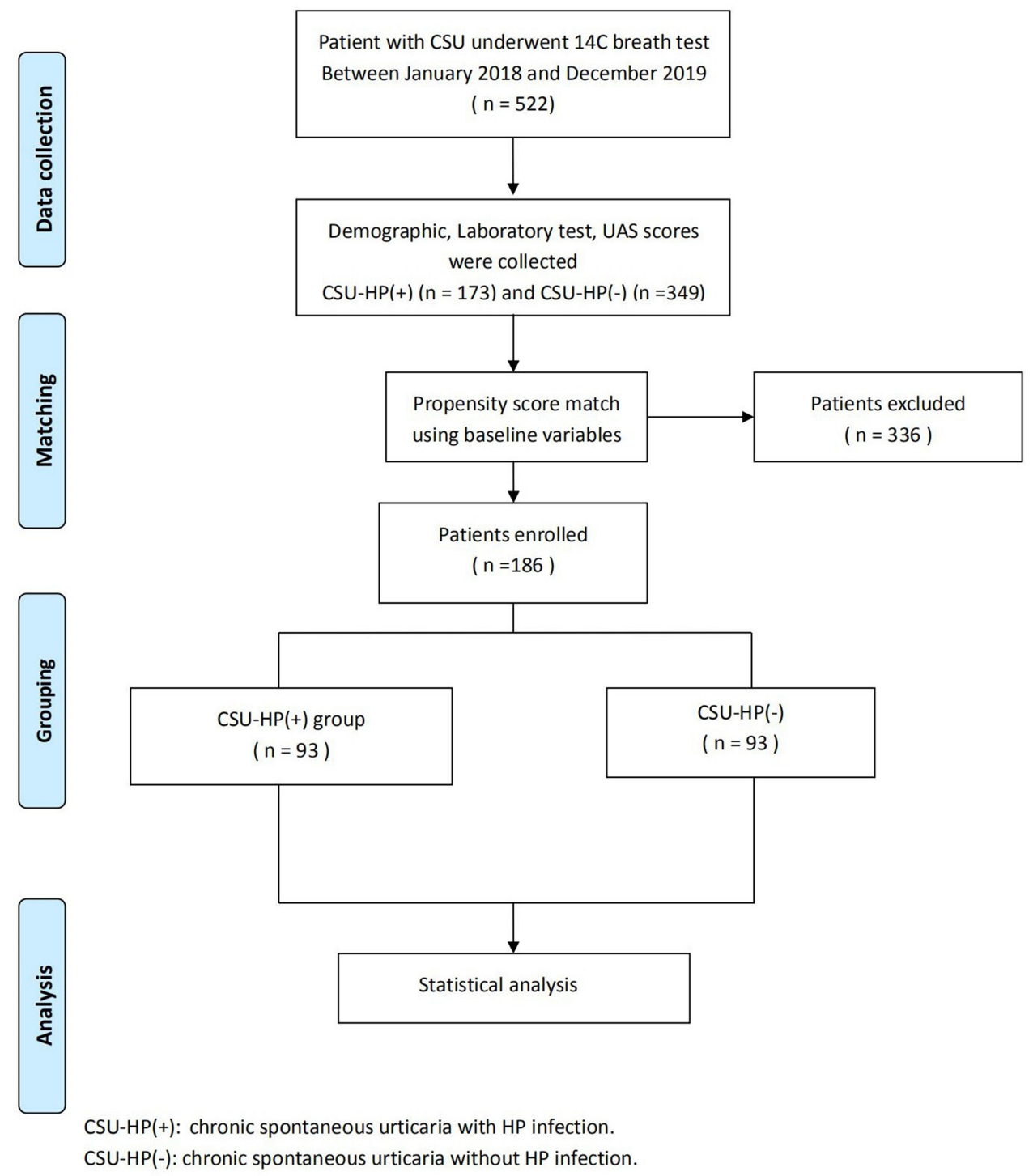

Figure I The study flow chart.

The pathogenesis of CU has not been fully clarified. Current studies show that the involvement of HP is likely due to the following aspects:

1. HP promotes the release of inflammatory mediators and activates mast cells and basophils. These release histamines and various vasoactive mediators into the peripheral blood, thus leading to the typical manifestations of urticaria, such as erythema and anemia. ${ }^{27-31}$

2. There is a proven relationship between HP infection and anti-IgE autoimmune reaction in CU. HP antigens induce the production of $\operatorname{IgE}$ receptor and anti-IgE antibodies, either by cross-reaction with gastric wall cells or by induction of gastrointestinal inflammation, which affects antigen absorption. It can also stimulate mast cells and basophils to degranulate and release histamine and participates in the pathogenesis of $\mathrm{CU} .^{32-34}$

3. Some protein products of HP, such as vacuolar toxin $\mathrm{A}$ and PC17 mixed protein components, stimulate mast cells to synthesize and secrete inflammatory mediators continuously. ${ }^{35-39}$

4. HP increases local infiltration of eosinophils and exacerbates CU symptoms by releasing toxic cations. ${ }^{40,41}$

5. HP infection destroys the gastric mucosal barrier, changes the permeability of gastric mucosa, increases the entry of food-derived antigens or other pro-inflammatory factors into the body, and stimulates the immune system of the host. This causes the host to acquire $\mathrm{CU}$ or aggravates existing CU. ${ }^{42-45}$ 
Table 2 Demographical Characteristics and Clinical Data of the Patients Before Propensity Score-Matching

\begin{tabular}{|c|c|c|c|}
\hline Variables & $\begin{array}{l}\text { CSU-HP(+) } \\
\text { Group }\end{array}$ & $\begin{array}{l}\text { CSU-HP(-) } \\
\text { Group }\end{array}$ & $P$ value \\
\hline \multicolumn{4}{|l|}{ Demographics } \\
\hline Patients & 173 & 349 & \\
\hline Age $(y$, mean $\pm S D)$ & $41.24 \pm 11.39$ & $38.91 \pm 13.30$ & 0.039 \\
\hline $18-39$ & 82 & 186 & \\
\hline 40-59 & 80 & 135 & \\
\hline $60-80$ & 11 & 28 & \\
\hline Gender(female\%) & $98(56.6 \%)$ & $229(65.6 \%)$ & 0.046 \\
\hline \multicolumn{4}{|l|}{ Laboratory test } \\
\hline WBC $\left(10^{9} / \mathrm{L}\right)$ & $6.22 \pm 1.48$ & $6.24 \pm 1.52$ & 0.876 \\
\hline $\operatorname{RBC}\left(10^{12} / \mathrm{L}\right)$ & $4.74 \pm 0.47$ & $4.73 \pm 0.47$ & 0.956 \\
\hline $\operatorname{PLT}\left(10^{9} / \mathrm{L}\right)$ & $231.98 . \pm 48.01$ & $224.19 \pm 49.21$ & 0.091 \\
\hline ALT & $23.73 \pm 8.59$ & $24.52 \pm 8.92$ & 0.334 \\
\hline $\mathrm{Cr}$ & $54.91 \pm 10.18$ & $55.53 \pm 9.85$ & 0.506 \\
\hline $\lg E+(n)$ & 64 & 147 & 0.261 \\
\hline $\begin{array}{l}\text { Pretreatment } \\
\text { symptoms } \\
\text { (upper } \\
\text { gastrointestinal) }\end{array}$ & 44 & 37 & 0.000 \\
\hline $18-39$ & 23 & 23 & \\
\hline $40-59$ & 19 & 11 & \\
\hline $60-80$ & 2 & 3 & \\
\hline $\begin{array}{l}\text { Post-treatment } \\
\text { symptoms } \\
\text { (upper } \\
\text { gastrointestinal) }\end{array}$ & 12 & 33 & 0.334 \\
\hline $18-39$ & 6 & 20 & \\
\hline $40-59$ & 6 & II & \\
\hline $60-80$ & 0 & 2 & \\
\hline UAS (0 week) & $3.76 \pm 0.72$ & $4.12 \pm 0.77$ & 0.000 \\
\hline UAS (I week) & $2.25 \pm 0.57$ & $2.30 \pm 0.64$ & 0.400 \\
\hline UAS (2week) & $0.73 \pm \pm 0.47$ & $0.88 \pm 0.35$ & 0.000 \\
\hline UAS (6week) & $0.07 \pm 0.26$ & $0.12 \pm 0.39$ & 0.058 \\
\hline
\end{tabular}

Abbreviations: WBC, white blood cells; RBC, red blood cells; PLT, platelet; ALT, alanine transaminase; $\mathrm{Cr}$, creatinine; IgE, immunoglobulin $\mathrm{E}$; UAS, urticaria activity score.

6. Abnormal immune function may be important in the pathogenesis of CU. The balance between Th1 and Th2 cells and their self-regulation is closely related to the onset of atopic and allergic diseases. HP infection promotes the secretion of IL-4 Th2 cytokines, and the cellular immune response to the Th2 immune response varies. Imbalance of Th1 and Th2 may increase. Th2 cell-secreted cytokines can contribute to B cell synthesis of IgE and adjust mast cell activity. This immune mechanism may induce and aggravate $\mathrm{CU} .^{30,31,46}$
Table 3 Demographical Characteristics and Clinical Data of the Patients After Propensity Score-Matching

\begin{tabular}{|c|c|c|c|}
\hline Variables & $\begin{array}{l}\text { CSU-HP(+) } \\
\text { Group }\end{array}$ & $\begin{array}{l}\text { CSU-HP(-) } \\
\text { Group }\end{array}$ & $P$ value \\
\hline Demographics & & & \\
\hline $\begin{array}{l}\text { Patients } \\
\qquad \begin{array}{l}\text { Age }(y \text {, mean } \pm \text { SD) } \\
\text { 18-39 } \\
40-59 \\
60-80 \\
\text { Gender(female\%) }\end{array}\end{array}$ & $\begin{array}{l}93 \\
40.61 \pm 11.85 \\
49 \\
37 \\
7 \\
56\end{array}$ & $\begin{array}{l}93 \\
38.37 \pm 13.37 \\
51 \\
35 \\
7 \\
57\end{array}$ & 1.000 \\
\hline $\begin{array}{l}\text { Laboratory } \\
\operatorname{WBC}\left(10^{9} / \mathrm{L}\right) \\
\operatorname{RBC}\left(10^{12} / \mathrm{L}\right) \\
\operatorname{PLT}\left(10^{9} / \mathrm{L}\right) \\
\operatorname{ALT} \\
\operatorname{Cr} \\
\operatorname{lgE}(+)(n)\end{array}$ & $\begin{array}{l}6.22 \pm 1.56 \\
4.75 \pm 0.50 \\
228.10 \pm 50.81 \\
24.11 \pm 9.05 \\
54.70 \pm 10.98 \\
32\end{array}$ & $\begin{array}{l}6.34 \pm 1.74 \\
4.74 \pm 0.52 \\
227.95 \pm 49.08 \\
25.12 \pm 8.09 \\
54.45 \pm 9.55 \\
36\end{array}$ & $\begin{array}{l}0.630 \\
0.927 \\
0.984 \\
0.430 \\
0.870 \\
0.665\end{array}$ \\
\hline $\begin{array}{l}\text { Pretreatment symptoms } \\
\text { (upper gastrointestinal) } \\
18-39 \\
40-59 \\
60-80\end{array}$ & $\begin{array}{l}21 \\
15 \\
5 \\
1\end{array}$ & $\begin{array}{l}5 \\
2 \\
2\end{array}$ & 0.036 \\
\hline $\begin{array}{l}\text { Post-treatment symptoms } \\
\text { (upper gastrointestinal) } \\
\text { 18-39 } \\
40-59 \\
60-80\end{array}$ & $\begin{array}{l}4 \\
3 \\
1 \\
0\end{array}$ & $\begin{array}{l}4 \\
2 \\
2\end{array}$ & 0.388 \\
\hline UAS(0 week) & $3.86 \pm 0.67$ & $3.74 \pm 0.7$ I & 0.101 \\
\hline UAS(I week) & $2.30 \pm 0.60$ & $2.16 \pm 0.56$ & 0.096 \\
\hline UAS(2 week) & $0.67 \pm 0.47$ & $0.91 \pm 0.28$ & 0.000 \\
\hline UAS(6 week) & $0.06 \pm 0.25$ & $0.10 \pm 0.36$ & 0.494 \\
\hline $\begin{array}{l}\text { Urticaria recurred in } 3 \\
\text { months }(n)\end{array}$ & 1 & 11 & 0.006 \\
\hline
\end{tabular}

Abbreviations: WBC, white blood cells; RBC, red blood cells; PLT, platelet; ALT, alanine transaminase; $\mathrm{Cr}$, creatinine; lgE, immunoglobulin $\mathrm{E}$; UAS, urticaria activity score.

7. HP infection produces urease, which breaks down urea to produce ammonia and $\mathrm{CO}_{2}$. Ammonia increases the $\mathrm{pH}$ value of gastric juices, stimulates gastrin production, increases gastric acid secretion, reduces gastric $\mathrm{pH}$, dilates gastric mucosal blood vessels, and increases the chance of contact between the body and food allergens. HP infection produces long-standing local or systemic inflammatory reactions in gastric mucosa, increasing skin vascular sensitivity and permeability. ${ }^{28,47}$ 
Currently, the results of studies on the relationship between HP and CU are inconsistent. ${ }^{48}$ There may be several reasons for this. HP infection may cause different pathogenic reactions due to differences in the susceptibility of the host, the environment, and the strain of HP. ${ }^{49}$ Between-study differences in detection methods, therapeutic agents, inclusion criteria, number of cases, age, race, region, individual differences, diagnostic criteria for HP infection, or breath detection methods will affect study populations.

Our study shows that HP may be related to the occurrence of CSU. For patients with HP-positive CSU, eradication of HP improves the treatment of CSU and reduces gastrointestinal symptoms. However, some patients with urticaria showed no significant improvement after HP eradication, indicating that HP infection is not the only factor in the pathogenesis of CSU in these patients. We found HP infection was more common in women with CSU than in men. The highest rates were in those aged 18-59 years. Gastrointestinal symptoms were higher in the CSU-HP(+) group than in the CSU-HP(-) group, with the highest incidence being seen in those aged 18-39 years. This study confirms that patients with CSU and upper gastrointestinal symptoms should be actively tested for HP. HP eradication treatment in combination with conventional treatment can show improvements within 2 weeks, reduce the recurrence rate after 3 months, and relieve gastrointestinal symptoms.

This study has several limitations. First, treatment outcomes were only assessed within 6 weeks and recurrence at 3 months. There was no attempt to trace the relationship between HP eradication failure or reinfection and urticaria onset over a longer time period. Second, outcome data were collected retrospectively and thus the results could be biased. Finally, due to the retrospective design of this study, the drugs used to eradicate HP were not identical.

Due to the limitations of the retrospective study design, and the fact that all the subjects came from one treatment center, further studies with larger samples are needed for clinical confirmation of our results.

\section{Funding}

No external funding received to conduct this study.

\section{Disclosure}

The authors declare that they have no conflicts of interest for this work.

\section{References}

1. Asero R, Tedeschi A, Cugno M. Treatment of refractory chronic urticaria: current and future therapeutic options. Am $J$ Clin Dermatol. 2013;14:481-488. doi:10.1007/s40257-013-0047-3

2. Zuberbier T, Asero R, Bindslev-Jensen C, et al. EAACIGA(2)LEN/ $\mathrm{EDF} / \mathrm{WAO}$ guideline: definition, classification and diagnosis of urticaria. Allergy. 2009;64:1417-1426. doi:10.1111/j.13989995.2009.02179.x

3. Zuberbier T, Alerer W, Asero R, et al. The EAACI/GA(2)LEN/EDF/ WAO Guideline for the definition, classification, diagnosis, and management of urticaria: the2013 revision and update. Allergy. 2014;69:868-887. doi:10.1111/all.12313

4. Hidvegi B, Nagy E, Szabo T. Correlation between T-cell and mast cell activity in patients with chronic urticaria. Int Arch Allergy Immunol. 2003;132:177-182. doi:10.1159/000073719

5. Prelipcean CC, Mihai C, Gogalniceanu P, et al. Extragastric manifestations of Helicobacter pylori infection. Rev Med Chir Soc Med Natlasi. 2007;111:575-583.

6. Yadav MK, Rishi JP, Nijawan S. Chronic urticaria and Helicobacter pylor. Indian $J$ Med Sci. 2008;62:157-162. doi:10.4103/00195359.40579

7. Wedi B, Raap U, Wieczorek D, Kapp A. Infections and chronic spontaneous urticaria. A review. Der Hautarzt; Zeitschrift fur Dermatologie, Venerologie, und verwandte Gebiete. 2010;61:758-764. doi:10.1007/s00105-010-1930-y

8. Fokuda S, Shimoyama T, Umegaki N, Mikami T, Nakano H, Mtmakata A. Effect of Helicobacter pylori eradication in the treatment of Japanese patients with chronic idiopathic urticaria. J Gastroenterol. 2004;39:827-830. doi:10.1007/s00535-004-1397-7

9. Magen E, Mishal J, Schlesinger M, Scharf S. Eradication of HP infection equally improves chronic urticaria with positive and negative autologous serum skin test. Helicobacter. 2007;12:567-571. doi:10.1111/j.1523-5378.2007.00522.x

10. Bülbül EB, Türker T, Gülten M, et al. Lack of correlation between Helicobacter pylori infection and autologous serum skin test in chronic idiopathic urticaria. Int J Dermatol. 2005;44:993-995.

11. Shakouri A, Compalati E, Lang DM, Khan DA. Effectiveness of Helicobacter pylori eradication in chronic tirticaria: evidence-basedanalysis using the grading of recommendations assessment, development, and evaluation system. Curr Opin Allergy Clin Immunol. 2010;10:362-369. doi:10.1097/ ACI.0b013e32833c79d7

12. Dauden E, Alionso IJ, Diez AG. H. pylori and chronic idiopathic urticaria. Int $J$ Dermatol. 2000;39:446-452. doi:10.1046/j.13654362.2000.00995.x

13. Shiotani A, Miyanishi T, Kamada T, et al. Helicobacter pylori infection and allergic diseases: epidemiologicalstudy in Japanese university students. J Gastroenterol Hepatol. 2008;23:e29-33. doi:10.1111/ j.1440-1746.2007.05107.x

14. Xiong F, Xiong M, Ma Z, Huang S, Li A, Liu S. Lack of association found between Helicobacter pylori infection and diarrhea-predominant irritable bowel syndrome: a multicenter retrospective study. Gastroenterol Res Pract. 2016;2016:3059201. doi: $10.1155 / 2016 / 3059201$

15. Hellmig S, Troch K, Ott SJ, et al. Role of Helicobacter pylori infection in the treatment and outcome of chronic urticaria. Helicobacter. 2008;13:341-345.

16. Atta AM, Rodrigues MZ, Sousa CP, et al. Autoantibody production in chronic idiopathic urticaria is not associated with Helicobacter pylori infection. Brax J Med Biol Res. 2004;37:13-17. doi:10.1590/S0100879X2004000100002

17. Bettoni O, Rizzini FL, Tosoni C, et al. Chronic urticaria induced by eradication therapy of Helicobacter pylori: a case report. Helicobacter. 2002;7:269. doi:10.1046/j.1523-5378.2002.00090.x 
18. Chinese Dermatology Society. Guidelines for the diagnosis and treatment of urticaria. Chin J Dermatol. 2007;591-593.

19. Weller K, Siebenhaar F, Hawro T, et al. Clinical measures of chronic urticaria. Immunol Allergy ClinNorth Am. 2017;37:35-49. doi:10.1016/j.iac.2016.08.005

20. Kapp A, Wedi B. Chronic urticatia: clinicalaspects and focus on a new antihistamine,levocetirizine. $J$ Drugs Dermatol. 2004;3:632-639.

21. Darlenski R, Kazandjieva J, Zuberbier T, et al. Chronic urticaria as a systemic disease. Clin Dermatol. 2014;32:420-423. doi:10.1016/j. clindermatol.2013.11.009

22. Gaig P, Garcia-Ortega P, Enrique E, Papo M, Quer JC, Richard C. Efficacy of the eradication of Helicobacter pylori infection in patients with chronic urticaria. A placebo-controlled double blind study. Allergol Immunopathol (Madr). 2002;30:255-258. doi:10.1016/ S0301-0546(02)79133-7

23. Gal E, Abuksis G, Fraser G, et al. 13C-urea breath test to validate eradication of Helicobacter pylori in an Israeli population. Isr Med Assoc J. 2003;5:98-100.

24. Tang L, Zhang Y, Gao X, et al. A Meta-analysis on the relations between Helicobacter pylori infection and chronic urticaria. Zhonghua Liu Xing Bing Xue Za Zhi. 2014;35:317-421.

25. Federman DG, Krisner RS, Moriarty JP, Concato J. The effect of antibiotic therapy for patients infected with $\mathrm{H}$. pylori who have chronic urticaria. $J$ Am Acad Dermatol. 2003;49:861-864. doi:10.1016/S0190-9622(03)00846-6

26. Campanati A, Gesuita R, Giannoni M, et al. Role of small intestinal bacterial overgrowth and Helicobacter pylori infection in chronic spontaneous urticaria: a prospective analysis. Acta Derm Venereol. 2013;93:161-164. doi:10.2340/00015555-1373

27. Munox-Lopex F. Helicobacter pylori and allergic disease. Allergol Immunopathol(Madr). 2003;31:253. doi:10.1016/S0301-0546(03) 79191-5

28. Karel'skaia IA, Ignat'ev VK. Helicobacter pylori infection in patients with chronic hives and asthma. Klin Med(Mosk). 2005;83:58-61.

29. Piazuelo MB, Camargo MC, Mera RM, et al. Eosinophils and mast cells in chronic gastritis: possibleimplications in carcino-genesis. Hum Pathol. 2008;39:1360-1369. doi:10.1016/j. humpath.2008.01.012

30. Ferrer M, Luquin E, Sanchez-Ibarrola A, et al. Secretion of cytokines, histamine and leukotrienes in chronic urticaria. Int Arch Allergy Immunol. 2002;129:254-260. doi:10.1159/000066772

31. Hidvegi B, Gonzalez-Cabello R, Temesvari E, et al. The effect of heat-inactivated Helicobacter pflori on the blastogenic response of peripheral blood mononuclear cells of patients with chronic urticaria. Int Arch Allergy Immunol. 2001;126:167-172. doi:10.1159/ 000049508

32. Sun L, Erxun K, Li J, et al. Correlations between antimast cell autoantibodies and chronic idiopathic urticaria. Ann Dermatol. 2014;26:145-149. doi:10.5021/ad.2014.26.2.145

33. Ortiz GG, Agustín MC, P E. M, et al. Chronic urticaria and Helicobacter pylori. Ann Allergy Asthma Immunol. 2001;86 (6):696-698. doi:10.1016/S1081-1206(10)62301-0

34. Dong Q, Hyde D, Herra C, et al. Identification of genes regulated by prolonged acid exposure in Helicobacter pylori. FEMS Microbiol Lett. 2001;196:245-249. doi:10.1111/j.1574-6968.2001.tb10572.x
35. Supajatura V, Ushio H, Wada A, et al. Cutting edge: vacA, a vacuolating cytotoxin of Helicobacter pylori, directly activates mast cells for migration and production of proinflammatory cytokines. $J$ Immunol. 2002;168:2603-2607. doi:10.4049/ jimmunol.168.6.2603

36. de Bernard M, Cappon A, Pancotto L, et al. The Helicobacter pylori VacA cytotoxin activates RBL-2H3 cells by inducing cytosolic calcium oscillations. Cell Microbiol. 2005;7:191-198. doi:10.1111/ j.1462-5822.2004.00446.x

37. Velin D, Bachmann D, Bouzourene H, Michetti P. Mast cells are critical mediators of vaccine-induced helicobacter clearance in the mouse model. Gastroenterology. 2005;129:142-155. doi:10.1053/j. gastro.2005.04.010

38. Tsai CC, Kuo TY, Hong ZW, et al. Helicobacter pylori neutrophil-activating protein induces release of histamine and interleukin-6 through $\mathrm{G}$ protein-mediated MAPKs and PI3K/Akt pathways in HMC-1 cells. Virulence. 2015;6:755-765. doi:10.1080/ 21505594.2015.1043505

39. Tan R-J, Sun H-Q, Zhang W, et al. A 21-35 kDa mixed protein component from Helicobacter pylori activates mast cells effectively in chronic spontaneous urticaria. Helicobacter. 2016;21:565-574. doi:10.1111/hel.12312

40. Moorchung N, Srivastava AN, Gupta NK, et al. The role of mast cells and eosinophils in chronic gastritis. Clin Exp Med. 2006;6:107-114. doi:10.1007/s10238-006-0104-9

41. Ojetti V, Armuzzi A, De Luca A, et al. Helicobacter pylori infection affects eosinophilic cationic protein in the gastric juice of patients with idiopathic chronic urticaria. Int Arch Allergy Immunol. 2001;125:66-72. doi:10.1159/000053798

42. Başkan EB, Türker T, Gülten M, et al. Lack of correlation between Helicobacter pylori infection and autologous serum skin test in chronic idiopathic urticaria. Int J Dermatol. 2005;44:993-995.

43. Fedwick JP, Lapointe TK, Meddings JB, et al. Helicobacter pylori activates myosin light-chain kinase to disrupt claudin-4 and claudin-5 and increase epithelial permeability. Infect Immun. 2005;73:7844-7852.

44. Zuberbier T. Urticaria Review. Allergy. 2003;58:1224-1234. doi:10.1046/j.1398-9995.2003.00327.x

45. Fedwick JP, Lapointe TK, Meddings JB, et al. Helicobacter pylori activates myosin light-chain kinase to disrupt claudin-4 and elaudin-5 and increase epithelial permeability. Infect Immun. 2005;73:7844-7852.

46. Ying S, Kikuchi Y, Meng Q, et al. TH1/TH2 cytokines and inflammatory cells in skin biopsy specimens from patients with chronic idiopathic urticaria: comparisionwith the allergen-induced late-phase cutaneous reaction. J Allergy Clin Immunol. 2002;109:694-700. doi:10.1067/mai.2002.123236

47. Magen E, Delgado JS. Helicobacter pylofi and skin autoimmune diseases. World J Gastroenterol. 2014;20:1510-1516. doi:10.3748/ wjg.v20.i6.1510

48. Hellmig S, Troch K, Ott SJ, et al. Role of Helicobacterpylori infection in the treatment and outcome of chronic urticaria. Helicobacte. 2011;13:341-345.

49. Ricci V, Romano M, Boquet P. Molecular cross-talk between Helicobacter pylori and human gastric mucosa. World J Gastroenterol. 2011;17:1383-1399. doi:10.3748/wjg.v17.i11.1383 


\section{Publish your work in this journal}

Clinical, Cosmetic and Investigational Dermatology is an international, peer-reviewed, open access, online journal that focuses on the latest clinical and experimental research in all aspects of skin disease and cosmetic interventions. This journal is indexed on CAS.

Submit your manuscript here: https://www.dovepress.com/clinical-cosmetic-and-investigational-dermatology-journal
The manuscript management system is completely online and includes a very quick and fair peer-review system, which is all easy to use. Visit http://www.dovepress.com/testimonials.php to read real quotes from published authors. 